\title{
A Study for Performance Based Design of Means of Escape in Fire
}

\author{
TAKEYOSHI TANAKA \\ Building Research Institute \\ Ministry of Construction \\ 1 Tatehara, Tsukuba-shi, Ibarakimen 305, Japan
}

\section{ABSTRACT}

It is important for a performance standard for fire safety of buildings to determine the safety criteria and design fires. In this study, the provisions for means of escape concerning shops in existing regulations of several countries are investigated and a preliminary consideration is made on the methodology to determine such a design fire that is able to reproduce the level of safety which have been realized for shops by complying with the existing regulations.

KEY WORDS: fire safety, performance standards, safety criteria, design fire, means of escape, department store, occupants density, exit width, maximum travel distance, available egress time.

\section{INTRODUCTION}

It is only after World War II that active research on bullding fire has begun. Nevertheless, the accomplishment in fire research to date may be said remarkable, particularly in the field of fire modeling in recent years. As a natural consequence, the fire research community has come to be more and more interested in developing a scientifically and engineering based performance standards for fire safety of buildings.

However, even though fire hazards may be understood clearer than before, it still rest on ambiguous consensus of communities to decide what level of safety is to be assured thereto. The safer, a community may be the happier, but at the same time it may resist to increase of cost of safety measures or excessive hindrance of everyday convenience. People live side by side with many kind of dangers anyway. So, a certain compromise is inevitable and in this sense the existing fire safety provisions in each country may be said an expression thereof.

By and all, direct loss by fire in most developed countries stays at an allowable level for a significant period, so it ray be said that their current interest is to reduce the total cost of fire while enjoying the present level of safety. The most responsible obstacle to cost effective fire safety measures is that only limited number of solutions are allowed by existing regulations. Once performance based standards are established, a variety of solutions will be made possible so that the most cost effective one can be selected.

For developing a performance based standard, it will be important that 
safety criteria and design fire are so determined as to make it possible to maintain the level of safety normally realized by complying with the existing regulations.

\section{INVESTIGATION INTO PROVISIONS ON MEANS OF ESCAPE}

The regulations in several countries concerning means of egress of department stores are investigated. The list of the regulations studied is given in REFERERCES.

Although all the countries have provisions for many factors affecting Iffe safety, the present investigation is concentrated on the provisions which might have significant impact on planning of buildings. The summary is given in Table 1 . It seems that the provisions for means of escape in these countries essentially address to the following purposes:

a) adequate arrangement of exits,

b) adequate number and capacity of exits, and

c) mitigation of fire hazard to facilitate escape movement.

\subsection{Arrangement of Exits}

Arrangement of exits is regulated by means of "maximum travel distance", "maximum length of common path of travel", "maximum dead end length" and so forth, but all of these are not necessarily prescribed in each country. It seems that maximum travel distance is considered to be the most important of these. Most countries require this to be $30-40 \mathrm{~m}$. The second most important may be maximum length of common path of travel, which is about one half of maximum travel distance in many countries.

What is interesting and puzzling as well to note is the variety of conditions among the countries to ease these requirements. These are relaxed by automatic sprinkler in USA, multiple escape directions in UK, protection of stair case in France, and height of floor in Japan.

\subsection{Number and Capacity of Exits}

The number of exit may be indirectly regulated by the maximum travel distance etc. but many countries have separate provisions for number of exits. Two or more exits are required approximately from $50 \quad-$ $280 \mathrm{III}^{2}$ of floor area.

Except Japan and Germany, occupants densities are incorporated into the calculation of the required width of exits. Dominantly, the densities are specified according to level of floor. The values thereof somewhat differ from a country to another. The capacity of exits actually required depends, however, not only on the occupants density but also on the rules of calculation of exit width, for instance, whether or not occupants loads of adjacent floors has to be taken into account makes difference.

In order to compare the widths required in the countries, sample calculations are made for a model department store having seven floors of the same area above the ground and a basement. Figures 1-3 indicate how much width of exits is required according to the floor areas. The increase of exit width due to the requirements of two way exits is neglected so as not to obscure the basic nature of exit capacity requirement, so more width may actually be required for small floor area.

widh of exits on 2nd - 7th floors: It may be said from Figure 1 that the required widths for upper floors vary considerably among countries, and the requirement in Japan looks to be most severe since this applies uniformly to all the upper floors.

widh of exits on street floor: High occupants density may be normally expected on street floors of department stores so that the line for the UK 
TABLE 1 Summary of regulatory requirements for means of escape for shops

\begin{tabular}{|c|c|c|c|c|c|c|c|c|}
\hline & & Australia & France & Japan & UK & & $\operatorname{LSC}($ IISA) & $\operatorname{tBC}(\operatorname{tiSA})$ \\
\hline \multirow[t]{6}{*}{$\begin{array}{l}\text { Specifi- } \\
\text { cations }\end{array}$} & $\begin{array}{l}\text { Maximum } \\
\text { travel } \\
\text { distance }\end{array}$ & $40 \mathrm{~m}$ & $\begin{array}{l}\text { a) a.p. -protected st. } 40 \mathrm{~m} \\
\text { |b)a.p. -non prtd.st. } \\
\text { |cldead end-ortd.st } \\
\text { |clom }\end{array}$ & $\begin{array}{l}\text { a) }>=15 \text { th flr } 30 \mathrm{rm} \\
\text { (b) }=<14 \text { th flr } 40 \mathrm{~m}\end{array}$ & $\begin{array}{l}\text { a) } 1 \text { direction } \\
\text { b) }>=2 \text { directions } \\
1\end{array}$ & $\begin{array}{l}18 \mathrm{~m} \\
30 \mathrm{~m}\end{array}$ & $\begin{array}{l}\text { (a) no sp. } \\
\text { (b) with sp. }\end{array}$ & $\begin{array}{l}\text { a)no sp. } \\
\text { (b)with sp. } \\
\text { (b) }\end{array}$ \\
\hline & $\begin{array}{l}\text { Max. direct } \\
\text { distance }\end{array}$ & & & & $\begin{array}{l}\text { a) } 1 \text { direction } \\
\text { (b) }>2 \text { directions }\end{array}$ & $\begin{array}{l}12 \mathrm{MI} \\
30 \mathrm{~m}\end{array}$ & & \\
\hline & $\begin{array}{l}\text { Max. common } \\
\text { path_length }\end{array}$ & $20 \mathrm{~m}$ & & $\begin{array}{lll}\mid \text { a) }>=15 \text { th } & \text { flr } & 15 \mathrm{~m} \\
\mid \text { b) }<=14 \text { th } & \text { flr } & 20 \mathrm{~m}\end{array}$ & $\begin{array}{l}\text { a) travel distance } \\
\text { (b) direct distance }\end{array}$ & $\begin{array}{l}18 \mathrm{~m} \\
12 \mathrm{~m}\end{array}$ & $\begin{array}{ll}\text { a) no sp. } & 15 \mathrm{~m} \\
\text { (b) with sR. } & 23 \mathrm{~m} \\
\end{array}$ & \\
\hline & $\begin{array}{l}\text { Max. dead ent } \\
\text { Length }\end{array}$ & (20m) & $10 \mathrm{~B}$ & $10 \mathrm{~m}$ & & & $\begin{array}{ll}\text { la) no sp. } & 6.1 \mathrm{~m} \\
\text { b) with so. }\end{array}$ & $6.1 \mathrm{~m}$ \\
\hline & $\begin{array}{l}\text { Distance } \\
\text { between exits }\end{array}$ & $9-60 \mathrm{~m}$ & & & & & $\begin{array}{l}>1 / 2 \text { di.agonal } \\
\text { space distance }\end{array}$ & \begin{tabular}{|c|}
$>1 / 2$ diagonal \\
space distance
\end{tabular} \\
\hline & $\begin{array}{l}\text { Min. number } \\
\text { of exits }\end{array}$ & $\begin{array}{l}\text { buildings: } \\
\text { a) }>25 \mathrm{~m} \\
\text { (b) }>=7 \text { flrs } 2\end{array}$ & \begin{tabular}{|l} 
a) $=<50 \mathrm{Ps}$. \\
b) $51-500 \mathrm{Ps}$. \\
c) $>500 \mathrm{Ps}$. \\
(c)
\end{tabular} & $\begin{array}{l}>=2 \text { for bldgs: } \\
\text { a) total area } \\
>1,500 \text { in } \\
\text { b) }>3 \text { floors }\end{array}$ & $\begin{array}{l}\text { l> } 2 \text { for all shops } \\
\text { except small ones }\end{array}$ & & $\begin{array}{l}\text { l } x=2 \text { for bldgs: } \\
\text { a) }>15 \text { m } \\
\text { b) trvi dist. } 323 \mathrm{~m} \\
\text { c) areas } 280 \mathrm{~m} \\
\text { (d) }>3 \text { floors }\end{array}$ & \begin{tabular}{|ll} 
a) $1-10 \mathrm{Ps}$ & 1 \\
b) $11-500 \mathrm{Ps}$ & 2 \\
c) $501-1,000 \mathrm{Ps}$ & 3 \\
|d) $>1,000 \mathrm{Ps}$ & 4
\end{tabular} \\
\hline \multirow[t]{3}{*}{$\begin{array}{l}\text { Occupant } \\
\text { density }\end{array}$} & Jpper floors & 0.2 & $\begin{array}{ll}\text { (a) }>=\text { 4th firs. } & 0.2(x 1 / 3) \\
\text { b) 3rd floor } & 0.5(\%) \\
\text { Le) 2nd floor } & 1.0(")\end{array}$ & & \multirow{3}{*}{\multicolumn{2}{|c|}{\begin{tabular}{|ll} 
Super market & 0.5 \\
Dept. store & \\
-main sales flr & 0.5 \\
-low density flr & 0.14
\end{tabular}}} & 0.18 & 0.18 \\
\hline & Street fleor & 0.33 & $2(\times 1 / 3)$ & & & & 0.36 & 0.36 \\
\hline & Loasements & 0.33 & 1 & & & & 0.36 & e. 36 \\
\hline \multirow[t]{2}{*}{$\begin{array}{l}\text { Fidth } \\
\text { exits }\end{array}$} & Corridor & $\begin{array}{l}\text { (a)1-100Ps. 1m } \\
\text { b) } 101-200 \mathrm{Ps} . \\
1+\frac{\mathrm{Pm}-100}{25} \times 0.25 \mathrm{~m} \\
\text { c) }>200 \mathrm{Ps} \\
2+\frac{\mathrm{Pn}-200}{75} \times 0.5 \mathrm{~m}\end{array}$ & $\begin{array}{l}\text { a) } 1-50 \mathrm{Ps} . \\
\text { b) } 51-100 \mathrm{Ps} . \\
0.9 \mathrm{mx} 2 \text { or } 1.4 \mathrm{mx} 1 \\
\text { c) } 101-500 \mathrm{Ps} \text {. } \\
\left(1+\frac{\mathrm{Pn}}{100}\right) \times 0.6 \mathrm{~m} \\
\text { d) }>500 \mathrm{Ps} \text {. } \\
\frac{\mathrm{Pn}}{100} \times 0.6 \mathrm{~m}\end{array}$ & $\begin{array}{l}\text { a) dpper floors } \\
0.27 \mathrm{An} / 100 \text { an } \\
\text { b) street floor } \\
0.6 \mathrm{~A} 0 / 100 \text { w } \\
\text { where An: area } \\
\text { of } \mathrm{n}^{\mathrm{m}} \text { th floor }\end{array}$ & $\begin{array}{ll}\text { a) } 1-50 \mathrm{Ps} . & 0.8 \mathrm{~m} \\
\text { b) } 50-110 \mathrm{Ps} . & 0.9 \mathrm{~m} \\
\text { c) } 111-220 \mathrm{Ps} . & 1.1 \mathrm{~m} \\
\text { d) }>220 \mathrm{Ps} \\
1.1+\frac{\mathrm{Pn}-220}{20} \times 0.1 \mathrm{~m}\end{array}$ & & $\begin{array}{l}\text { a) upper floors } \\
\frac{\mathrm{Pn}}{100} \times 0.56 \mathrm{~m} \\
\text { b) street floor } \\
\frac{\mathrm{P}+\mathrm{P}_{0}+\mathrm{P}}{100}\end{array}$ & $\begin{array}{l}\text { (a) upper floors } \\
\frac{\mathrm{Pn}_{\mathrm{n}}}{50} \times 0.3 \mathrm{n} \\
\text { (b) street floor } \\
\frac{\mathrm{P}_{-1} / 2+\mathrm{P}_{0}+\mathrm{P}_{1} / 2}{50} \\
\frac{50}{50}\end{array}$ \\
\hline & Stairs & $\begin{array}{l}\text { a) } 1-100 \mathrm{Ps} \text {. } 1 \mathrm{~m} \\
\text { b) } 101-200 \mathrm{Ps} . \\
1+\frac{\mathrm{Pn}-100}{25} \times 0.25 \mathrm{~m} \\
\text { (c) }>200 \mathrm{Ps} \\
2+\frac{\mathrm{Pm}-200}{60} \times 0.5 \mathrm{~m}\end{array}$ & $\begin{array}{l}\text { Same rule as corridor, } \\
\text { Pn being the total } \\
\text { occupants served by the } \\
\text { part of the stairs }\end{array}$ & $\begin{array}{l}0.6 \text { kmax } / 100 \text { n } \\
\text { where Amax: Max. } \\
\text { area of upper } \\
\text { floors }\end{array}$ & $\begin{array}{l}1.1+\frac{\operatorname{mnt}-40(n+4.5)}{5(n+3)} \\
\text { where } \\
n \text { :number of floor } \\
\text { served } \\
\text { Pnt:number of total } \\
\text { eccupants serve }\end{array}$ & ors & $\frac{\mathrm{Pn}}{75} \times 0.56 \mathrm{~m}$ & $\frac{\mathrm{P}_{\mathrm{n}}+\mathrm{P}_{\mathrm{n}+1} / 2+\mathrm{P}_{\mathrm{n}+2} / 4}{50}$ \\
\hline \multirow{2}{*}{$\begin{array}{l}\text { Built }- \text { in } \\
\text { systems to } \\
\text { facilitate } \\
\text { escape }\end{array}$} & $\begin{array}{l}\text { Smoke } \\
\text { control }\end{array}$ & all shops & shops $>300 \mathrm{~m}^{2}$ & room $>100 \mathrm{~m}^{2}$ & & & & \\
\hline & Sprinkler & $\begin{array}{l}\text { a) building }>25 \mathrm{~m} \\
\text { b) space }>3,500 \mathrm{~m}\end{array}$ & $\begin{array}{l}\text { sales area } \\
>3,000 \mathrm{~m}\end{array}$ & $\begin{array}{l}\text { a) }>=11 \text { th flr } \&>100 \mathrm{~m}^{2} \\
\text { ib) total area } a>3000 \mathrm{~m} \\
\&>200 \mathrm{a} \\
\text { c) } 2 \text { space }>1,500 \mathrm{~m}\end{array}$ & $\begin{array}{l}\text { compartment } 2^{\text {or }} \\
\text { floor }>2000 \mathrm{~m}\end{array}$ & & $\begin{array}{l}\mid \text { a) floor } 21100 \mathrm{~m}^{2} \\
\text { |b) total area } 2200 \mathrm{~m} \\
\mid \text { c) }>=4 \text { floors } \\
\mid \text { d) }>23 \mathrm{~m}\end{array}$ & $\begin{array}{l}\text { a) floor }>1100 m^{2} \\
\text { | b) total area }>2200 m^{2} \\
\text { |c }>=4 \text { floors } \\
\mid \text { d) }>23 \text { m }\end{array}$ \\
\hline
\end{tabular}

Max.:Maxinum, Ps.:Persons, PniNumber of persons on n-th floor, flr:floor, trvl:travel, dist.:distance, sp.:sprinkler 




Sylibols:

A : Australia

BH: UK high density floor

BL: UK low density floor

F2: France 2nd floor

F3: France 3rd floor

F4: France $>=4$ th floor

$\mathbf{J}$ : Japan

$L$ : USA Life Safety Code

U : USA Uniform Bldg. Code

FIGURE 1 Required exit widths for upper floors of shop buildings

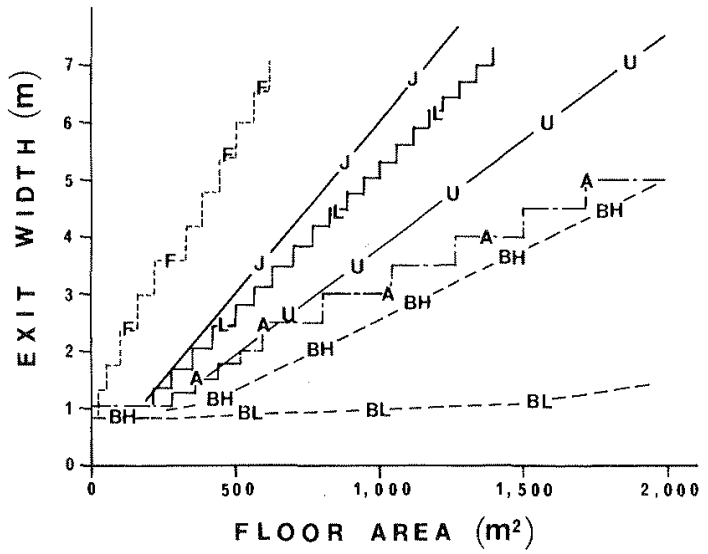

\section{Symbols:}

A : Australia

BH: UK high density floor

BL: UK low density floor

J : Japan

L. : USA Life Safety Code

$\mathbf{U}$ : USA Uniform Bldg. Code

FIGURE 2 Required exit widths for street floors of shop buildings

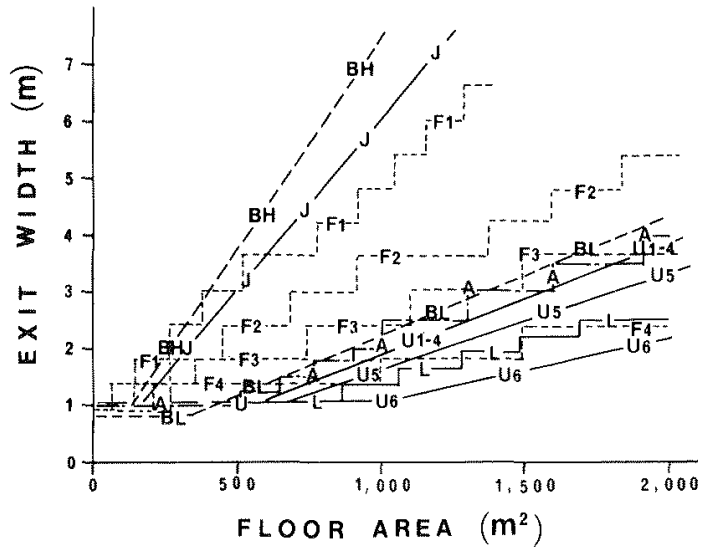

Syubols :

A : Australia

BI: UK high density level

BL: UK low density level

F1: France 1st level

F2: France 2nd level

F3: France 3rd level

F4: France 4th level

J : Japan

L : USA Life Safety Code

U1-4: USA UBC 1-4 levels

U5: USA UBC 5 th level

U6: USA UBC 6th level

FIGURE 3 Required widths for stairs of shop buildings 
requirement for low density area can be neglected from Figure 2. Even so, the difference among the countries is still significant.

widh of stairs: It will be said from Figure 3 that the requirement of Japan is extremely high if the special floors, namely, 1 st and 2nd levels, in France and UK high density floor are disregarded. other countries seem to have similar level of requirements.

\subsection{Equipments to Mitigate Hazard of Fire}

Smoke control and sprinkler are considered to be the most important means to mitigate hazard due to fire so to facilitate safe escape behavior. In the USA, Japan and Australia, sprinklers are required according to height of building, area of each floor or compartment and total floor area of building. In UK and France, the requirements seem to be only on compartment area basis. Any smoke control measure is not required for floor area in the USA and Germany, nor in UK. By contrast, some sort of smoke control means are required when a space exceeds a certain area in Japan, France and Australia.

\section{INTERPRETATIONS OF EXIT REQUIREMENTS IN EXISTTING REGULATIONS}

As was seen in the above, capacity of exits and maximum travel distance are regarded to be the most important requirements for safe escape in the event of fire. Then what level of safety is promised by these requirements? In the following this question is considered taking a floor of a department store as an example.

\subsection{Scenario of Evacuation}

The scenarios of the evacuation assuned here is as follows:

a)occupants locate uniformly over the floor before the start of evacuation,

b) evacuation starts simultaneously when the smoke layer descends to the height $Z_{1}$,

c)troubles arise in evacuation when the smoke layer descends to the height $Z_{2}$, and

d) heat release rate of fire $Q$ increases proportionally to square of time, i.e. $\mathrm{Q}=\mathrm{Q}_{0} \mathrm{t}^{2}$.

We learn by ample experience of fire that evacuations never start immediately after ignition of fire. Even though fire alarms are sounding, people tend to seek further information or make sure of fire. Often it is only after they have witnessed the fire or recognized the danger that they rush to escape. The smoke layer height $z_{1}$ is the parameter which represents such a stage. This may be specified as $\mathrm{Z}_{1}=0.9 \mathrm{H}$, $\mathrm{H}$ being the ceiling height. The height $\mathrm{Z}_{2}$ represents the stage at which a hazardous situation for evacuation takes place. People might be able to escape through smoke for a short period of time, but at design stage the criteria should be such that no occupant is allowed to be exposed to smoke. So $Z_{2}$ may be specified as $Z_{2}=1.6+0.1 \mathrm{H}$ for instance[12]. An alternative criterion such as $z_{2}=h_{d}$ could be taken, $h_{d}$ being the exit doorway height, when smoke should be prevented from invading stalr cases through exit doorways, which are expected to be kept open during floor evacuation.

The $t^{2}$ fire $Q=Q_{0} t^{2}$, which is getting popularity over the world as a design fire for some applications, will be a reasonably adequate model representing fire at initial stage. Needless to say, the larger the value of coefficient $Q_{0}$, the faster the growth of fire. 


\subsection{Available Egress Time}

From the scenario assumed in the above, it follows that the available egress time of a sales floor is given as the time that smoke layer descends from $Z_{1}$ to $Z_{2}$. In a space with floor area $A$, ceiling height $\mathrm{H}$ and $\mathrm{t}^{\mathrm{n}}$ fire $\mathrm{Q}=\mathrm{Q}_{0} \mathrm{t}^{\mathrm{n}}$, the time $\mathrm{t}$ that the smoke layer descends to height $Z$ is given as [13]:

$t=\left\{\frac{\mathrm{n}+3}{2} \frac{1 /\left(\mathrm{Z}+\mathrm{Z}_{0}\right)^{2 / 3}-1 /\left(\mathrm{H}+\mathrm{Z}_{0}\right)^{2 / 3}}{\mathrm{k} \mathrm{Q}_{0}{ }^{1 / 3} / \mathrm{A}}\right\}^{3 /(\mathrm{n}+3)}$

where

$k=0.21\left(\frac{\rho_{\mathrm{a}}^{2} \mathrm{~g}^{1 / 3}}{\mathrm{CpTa}}\right) \frac{1}{\rho_{\mathrm{s}}}$

and $\rho_{\mathrm{a}}$ and $\rho_{\mathrm{S}}$ are the densities of ambient air and smoke layer, respectively, $\mathrm{Ta}$ is the ambient air temperature, $\mathrm{Cp}$ and $\mathrm{g}$ are specific heat of air and acceleration due to gravity and $Z_{0}$ is the distance of the virtual point heat source.

Since $n=2$ in this particular case, Eq. (1) becomes as

$t=\left\{\frac{5}{2} \frac{1 /\left(\mathrm{Z}+\mathrm{Z}_{0}\right)^{2 / 3}-1 /\left(\mathrm{H}+\mathrm{Z}_{0}\right)^{2 / 3}}{\mathrm{kQ}_{0}{ }^{1 / 3} / \Lambda}\right\}^{3 / 5}$

Therefore, $t_{1}$ and $t_{2}$ being the times at which $z$ becomes $z_{1}$ and $Z_{2}$, respectively,

$t_{1}=C_{1}\left(\frac{5}{2 k}\right)^{3 / 5}\left(\frac{Q_{0}}{A^{3}}\right)^{1 / 5}, \quad t_{2}=C_{2}\left(\frac{5}{2 k}\right)^{3 / 5}\left(\frac{Q_{0}}{A^{3}}\right)^{1 / 5}$

where

$C_{1}=\left\{1 /\left(\mathrm{Z}_{1}+\mathrm{Z}_{0}\right)^{2 / 3}-1 /\left(\mathrm{H}+\mathrm{Z}_{0}\right)^{2 / 3}\right\}^{3 / 5}, \quad C_{2}=\left\{1 /\left(\mathrm{Z}_{2}+\mathrm{Z}_{0}\right)^{2 / 3}-1 /\left(\mathrm{H}+\mathrm{Z}_{0}\right)^{2 / 3}\right\}^{3 / 5}$

So, the available egress time $t_{A}$ is given as

$t_{A}=t_{2}-t_{1}=\frac{\left(C_{2}-C_{1}\right)(5 / 2 k)^{3 / 5}}{Q_{0}{ }^{1 / 5}} \cdot A^{3 / 5}$

that is, in a space with $\mathrm{t}^{2}$ fire, the available egress time increases proportionally to the area to $3 / 5$.

Incidentally, for a constant fire $Q=Q_{0}$, following the same process as in the above with $n=0$, the available egress time becomes as

$\mathrm{t}_{\mathrm{A}}=\mathrm{C}^{\prime}\left\{(3 / 2 \mathrm{k}) / \mathrm{Q}_{0}{ }^{1 / 3}\right\} \mathrm{A}$

where

$C^{\prime}=1 /\left(Z_{2}+Z_{0}\right)^{2 / 3}-1 /\left(Z_{1}+Z_{0}\right)^{2 / 3}$

that is, the available egress time is proportional to area. 


\subsection{Available Egress Time and Provisions for Exits}

In the following, let's consider how available egress time is related with exit width and maximum travel distance. Assuming that occupants are located uniformly over floor area, egress time is almost controlled by the larger of the exit time through doorway $t_{E}$ and travel time $t_{L}$ given by:

$\mathrm{t}_{\mathrm{E}}=\mathrm{pA} / \mathrm{NB}$

$\mathrm{t}_{\mathrm{L}}=\mathrm{L} / \mathrm{V}$

where $p, B, L, V$ and $N$ are occupants density(persons $/ \mathrm{m}^{2}$ ), exit width(m), maximum travel distance(m), travel speed $(\mathrm{m} / \mathrm{s})$ and exit flow efficiency (persons $/ \mathrm{m} / \mathrm{s}$ ). Equating $\mathrm{t}_{\mathrm{A}}$ of $\mathrm{Eq} .(6)$ and $\mathrm{t}_{\mathrm{E}}$ gives

$B=(p / N)\left\{Q_{0}{ }^{1 / 5} /\left(C_{2}-C_{1}\right)(5 / 2 k)^{3 / 5}\right\} A^{2 / 5}$

that is, exit width should be increased in proportion to area to $2 / 5$. Next, likewise equating $t_{A}$ with $t_{L}$,

$\mathrm{L}=\mathrm{v}\left(\mathrm{C}_{2}-\mathrm{C}_{1}\right)\left\{(5 / 2 \mathrm{k})^{3 / 5} / \mathrm{Q}_{0}{ }^{1 / 5}\right\} \mathrm{A}^{3 / 5}$

that is, maximum travel distance can be increased in proportion to area to $3 / 5$. However, it may be necessary to add a safety factor taking into account that people may wander into dead ends or miss exit directions.

Incidentally, for constant fire, B and L become as follows:

$\mathrm{B}=(\mathrm{p} / \mathrm{N}) \mathrm{Q}_{0}^{1 / 3} / \mathrm{C}^{\prime}(3 / 2 \mathrm{k})$

$L=v C^{\prime}\left\{(3 / 2 k) / Q_{0}{ }^{1 / 3}\right\} \mathrm{A}$

respectively. So, exit width can be constant regardless of area and maximum travel distance can be increased in proportion to area.

\subsection{Consideration on Design Fire}

Next, let's try to find out the fire that the prescriptive provisions assume implicitly. From Figure 1, it looks that the existing regulations consider the exit widths as shown in Table 2 are necessary for sales area of $2,000 \mathrm{~m}^{2}$. Now, from Eq. (11) we have

$\mathrm{Q}_{0}{ }^{1 / 5} /\left\{\left(\mathrm{C}_{2}-\mathrm{C}_{1}\right)(5 / 2 \mathrm{k})^{3 / 5}\right\}=\mathrm{NB} / \mathrm{pA}^{2 / 5}$

TABLE 2 Required exit width for sales floor of $2,000 \mathbf{m}^{2}$

\begin{tabular}{|c|c|c|c|c|}
\hline $\begin{array}{l}\text { Country } \\
\text { Regulation }\end{array}$ & $\begin{array}{l}\text { Occupant (b) } \\
\text { density }\end{array}$ & $\begin{array}{l}\text { Exit (c) } \\
\text { width }\end{array}$ & $\mathrm{NB} / \mathrm{pA}^{2 / 5}$ & $\begin{array}{l}\text { Available egress } \\
\text { time }\left(\mathrm{xA}^{3 / 5}\right)\end{array}$ \\
\hline \multirow{2}{*}{$\begin{array}{l}\text { UK high density } \\
\text { low density }\end{array}$} & 0.5 & 5.0 & 0.717 & 1.39 \\
\hline & 0.143 & 1.4 & 0.702 & 1.42 \\
\hline USA & 0.18 & 2.2 & 0.876 & 1.14 \\
\hline UBC & 0.18 & 2.1 & 0.836 & 1.20 \\
\hline Australia & 0.2 & 3.5 & 1.25 & 0.80 \\
\hline France 2nd FL & $1.0 / 3$ & 4.2 & 0.903 & 1.11 \\
\hline 3rd FL & $0.5 / 3$ & 3.0 & 1.28 & 0.78 \\
\hline$>=4$ th FL & $0.2 / 3$ & 1.8 & 1.94 & 0.52 \\
\hline \multicolumn{3}{|c|}{ Average(Last one omitted for big difference) } & 0.94 & 1.06 \\
\hline
\end{tabular}


Note that the left hand side of Eq. (15) depend only on fire condition. Substituting the values in columns (a), (b), $A=2,000$ and $\mathrm{N}=1.5$ into the right hand side of Eq. (15) yields the values in column (c). Using these values to Eq. (6), available egress time can be obtained as in column (d) in the same table. Since fire condition and the resulting available egress time should have nothing to do with occupants density, the difference in the numbers implies that the empirical provisions are somewhat inconsistent on the assumption of fire. Taking the average of the values, we have

Left hand side of Eq.(15) $=0.94$

This is the fire conditions that give the available egress time as: $t_{A}=1.06 A^{3 / 5}$

Using the value of Eq.(16), the exit width for a space with occupants density $p$ can be determined as

$\mathrm{B}=0.62 \mathrm{pA}^{2 / 5}$

The solid lines in Figure 4 show the values of B calculated using Eq.(18). Where area is small, B shown in Figure 4 may seem larger than the values of the existing provisions in Figure 1, however, the difference in practice is not as significant as it might seem since the latter usually requires two or more exits in this area.



Symbols:

P : Occupants density

II : Ceiling height

NO SP.: No sprinkler

W. SP.: With sprinkler

FIGURE 4 Calculated exit widths required for different conditions

Coming back to design fire issue, the left hand side of Eq.(15) is considered to indicate the fire conditions that the existing regulations implicitly assume. In a strict sense, (5/2k) in Eq.(15) is not a constant since it depends on ambient air and smoke layer temperatures, but here this is assumed to be almost constant. Calculation using $\mathrm{Ta}=293 \mathrm{~K}$ and $\mathrm{Ts}=373$ K yields

$\mathrm{Q}_{0}{ }^{1 / 5} /\left(\mathrm{C}_{2}-\mathrm{C}_{1}\right)=7.33$

Note that the numerator $Q_{0}{ }^{1 / 5}$ represents growth of fire and the denominator $\mathrm{C}_{2}-\mathrm{C}_{1}$ represents safety criteria. There is a degree of freedom 
in determining the two parameters. Even though one of then is arbitrarily specifled, the agreement with the empirical standards is preserved as long as the ratio is kept at the value of $\mathrm{Eq} .(16)$ or (19). Here, $\mathrm{C}_{2}-\mathrm{C}_{1}$ is first determined since it is easier. As can be seen in Eq. (5), this is a function of $\mathrm{H}, \mathrm{Z}_{1}, \mathrm{Z}_{2}$ and $\mathrm{Z}_{0}$. If the values given in Case 1 and 2 of Table 3 are accepted as the standard conditions, $Q_{0}$ can be obtained as follows:

Performing calculation for Case $1, C_{2}-C_{1}=0.1916-0.1012=0.0904$. So, $Q_{0}$ is calculated as $Q_{0}=(7.33 \times 0.0904)^{5}=1.28 \times 10^{-1}$. That $i s$, it follows that the design fire $Q_{1}$ for Case 1 is

$\mathrm{Q}_{1}=1.28 \times 10^{-1} \mathrm{t}^{2}$

Likewise for Case 2 , the design fire $Q_{2}$ is obtained as

$\mathrm{Q}_{2}=1.44 \times 10^{-2} \mathrm{t}^{2}$

The connotation of the difference between the two fires is that the more rigorous the safety criteria, the less severe the design fire has to be for the economy of fire safety measures.

\section{TABLE 3 Conditions for sapple calculations}

\begin{tabular}{|c|c|c|c|c|}
\hline Paralneter & Symbol. & Case 1 & Case 2 & Case 3 \\
\hline Ceiling height(II) & $H$ & 2.5 & 2.5 & 3.0 \\
\hline $\begin{array}{l}\text { Smoke layer height } \\
\text { at start of evac. (m) }\end{array}$ & $z_{1}$ & $0.9 \mathrm{H}=2.25$ & 2.25 & $0.9 \mathrm{H}=2.7$ \\
\hline $\begin{array}{l}\text { Allowable smoke layer } \\
\text { height (m) }\end{array}$ & $z_{2}$ & $1.6+0.1 \mathrm{H}=1.85$ & $\mathrm{hd}=2.0$ & $1.6+0.1 \mathrm{H}=1,9$ \\
\hline Constant for $t^{2}$ fire & $Q_{0}$ & $1.28 \times 10^{-1}(*)$ & $1.44 \times 10^{-2}(*)$ & $1.28 \times 10^{-1}$ \\
\hline
\end{tabular}

(*) Calculated Result

\subsection{Application of Safety Criteria and Design Fire}

Lastly, examples are given to show how safety criteria and design fire can be applied to different conditions once the design fire has been established.

\section{(i) Space with high ceiling}

Let's consider the case shown as Case 3 in Table 3 , that is, the case with $3.0 \mathrm{~m}$ ceiling height, the way to determine layer height criteria and the fire being the same as Gase 1. Given the values in Case 3 , calculation of Eq. (6) yields $t_{A}=1.72 A^{3 / 5}$, that is, the available egress time increases by $50-60 \%$ from Case 1 , in which the ceiling height is $2.5 \mathrm{~m}$. Accordingly, the exit width $B$ can be $B=0.39 \mathrm{pA}^{275}$. This value of $\mathrm{B}$ for $\mathrm{p}=0.5$ and 1.0 is shown by the broken lines in Figure 4 .

\section{(ii) Space with automatic sprinklers}

The significance of automatic sprinklers on safety of egress is always an interesting issue to look into. According to statistics automatic sprinklers are fairly reliable to extinguish fires as long as the heat release is large enough to actuate sprinkler heads. So, only what we have to concern is relatively small fires which cannot be put out by sprinklers.

For celing mounted sprinklers, maximum heat release rate that cannot actuate sprinkler heads Qmax may be given as[14] 
$Q \max =0.08 \mathrm{r}\left\{\left(\mathrm{Tc}-\mathrm{T}_{0}+\mathrm{dT}\right)\left(\mathrm{H}+\mathrm{Z}_{0}\right)\right\}^{3 / 2}$

where $r$ is the lateral distance between fire plume axis and the closest sprinkler head, $\mathrm{Tc}, \mathrm{T}_{0}$ and $\mathrm{dT}$ are the nominal actuation temperature of the head, ambient temperature and margin temperature for sure actuation, respectively. If the spacing of the sprinkler heads is $4 \mathrm{~m}, \mathrm{r}=2 \sqrt{2}=$ $2.82 \mathrm{~m}$ is the largest distance possible, so performing the calculation for the example where $\mathrm{H}=2.5 \mathrm{~m}, \mathrm{TC}=72{ }^{\circ} \mathrm{C}, \mathrm{T}_{0}=20^{\circ} \mathrm{C}, \mathrm{dT}=20^{\circ} \mathrm{C}$ and $\mathrm{Z}_{0}=1 \mathrm{~m}$, we have $Q \max =900 \mathrm{~kW}$. Therefore, it is sufficient to as sure safety for at most a $900 \mathrm{~kW}$ fire in this case Also, $\mathrm{C}^{\prime}$ is calculated using Eq. (6) as $\mathrm{C}^{\prime}=$ $1 /(1.85+1.0)^{2 / 3}-1 /(2.25+1.0)^{2 / 3}=0.0417$. Substituting these values into Eq. (13), the exit width needed for this space is obtained as $B=8.2 \mathrm{p}$. Therefore in case of $\mathrm{p}=0.2$ and $0.5, \mathrm{~B}=1.64 \mathrm{~m}$ and $4.1 \mathrm{~m}$, respectively.

Incidentally, if $\mathrm{H}=3.0 \mathrm{~m}, \mathrm{Qmax}=1,100 \mathrm{~kW}$, and $\mathrm{C}^{\prime}=0.0737$ so that exit width $B$ becomes as $B=5.0 p$. These values are shown also in Figure 4 . It can be seen that the exit width can be considerably relaxed by automatic sprinklers.

\section{CONCLUDING REMARKS}

In developing a performance based standards for fire safety of buildings, to establish adequate safety criteria and design fire is as important as to develop engineering tools for fire prediction. These criteria and design fire have to be so determined as to be harmonized with building economy. In this paper a preliminary consideration is made for this purpose, but more systematic studies using computer fire models will have to be carried out.

\section{REFERENCES}

1. Building Code of Australia, AUBRCC, 1988.

2. Reglement de Securite contre l'Incendie - Relatif aux Etablissements Recevant du Public, 4eme edition, Ministere de l'Interieur, 1987.

3. Securite contre I'Incendie - Etablissements Recevant du Public, Magasins, Centre Commerciaux, Journal officiel de la Republique Francaise 1477 II.

4. La Reglementation de la Construction en Republique Federale d'Allemagne, Norex, 1987.

5. Building Standard Law, Japan.

6. Fire Service Law, Japan.

7. Tokyo Metropolitan Ordinance for Building Fire Safety, Tokyo.

8. The Building Regulations 1985 - Mandatory rules for means of escape in case of fire, Department of Environment and Welsh Office, Her Majesty's Stationary office, 1985.

9. British Standard 5585 - Fire precautions in the design and construction of buildings, Part 2: 1985 Code of practice for shops,

BSI.

10. Life Safety Code 1985 , NFPA.

11]Uniform Building Code, 1988 edition.

12. Total Fire Safety Design Method of Buildings, Report of Technology Development Project, MoC, 1989. (in Japanese)

13. Tanaka, T., Yamana, T. : Smoke Control in Large Scale Spaces, Fire Science and Technology Vol.5 No.1, 1985.

14. Alpert, R.L. : Calculation of response time of ceiling-mounted fire detectors, Fire Technology, 8, 1972. 